\title{
Structural Characteristics of Bimetallic Catalysts Supported on Nano-Ceria
}

\author{
J. F. Bozeman III and H. Huang \\ Department of Mechanical and Materials Engineering, Wright State University, Dayton, OH 45435, USA \\ Correspondence should be addressed to H. Huang, hong.huang@wright.edu
}

Received 22 December 2010; Accepted 4 February 2011

Academic Editor: Zhenmeng Peng

Copyright ( $) 2011$ J. F. Bozeman III and H. Huang. This is an open access article distributed under the Creative Commons Attribution License, which permits unrestricted use, distribution, and reproduction in any medium, provided the original work is properly cited.

\begin{abstract}
$\mathrm{Cu}$-Pt bimetal catalysts supported on nanocrystalline $\mathrm{CeO}_{2}$ (nano-ceria) are synthesized via the low-cost sol-gel approach followed by impregnation processing. The average particle size of the catalytic composites is $63 \mathrm{~nm}$. Ceria nanopowders sequentially impregnated in copper solution and then in Pt solution transformed into Pt-skin-structured $\mathrm{Cu}$ - $\mathrm{Pt} / \mathrm{ceria}$ nanocomposite, based on the surface elemental and bulk compositional analyses. The ceria supporter has a fluorite structure, but the structure of $\mathrm{Cu}$ and Pt catalytic contents, not detected by X-ray diffraction spectroscopy due to the low loading level, is yet conclusive. The bimetallic catalytic nanocomposites may potentially serve as sulfur-tolerant anode in solid oxide fuel cells.
\end{abstract}

\section{Introduction}

Fuel Cells are one of the key technologies in the field of renewable and clean energy because they have unique characteristics such as high energy density, high conversion efficiency, rapid refueling, and low noise. Solid oxide fuel cells (SOFCs), operated at temperatures of $600-1000^{\circ} \mathrm{C}$, have potentials to directly utilize fuels, such as natural gas and biogases, with no need of high-grade prepurifying process [1-4]. Enabling such capabilities of SOFCs at no sacrifice of energy conversion efficiency is greatly beneficial for commercialization. However, economical low-cleaning fuels usually contain hydrogen sulfide up to hundreds of ppm level [5-12] causing dramatic decrease in the fuel cell performances [13-21]. The Ni/yttria-stabilized zirconia (YSZ) cermet anode, commonly utilized in SOFCs, is susceptive to sulfur in the following two aspects [22-25]: (1) $\mathrm{H}_{2} \mathrm{~S}$ absorbs on surface active sites of Ni catalyst, inhibiting effective catalytic functionality for fuel oxidation; and (2) Nickel sulfide forms resulting in complete loss of catalytic activity and conductivity. Consequently, Ni/YSZ cermet can only tolerate $0.1 \mathrm{ppm}$ of sulfur in the fuels.

Ceria successfully served as the sulfur-sorbent and sulfurremoval materials $[26,27]$. Zhan and Barnett reported that sulfur could be reversibly and efficiently adsorbed on the surface of ceria and doped ceria over a wide temperature range of $350-800^{\circ} \mathrm{C}$ [27], matching the operating temperatures of SOFCs. Therefore, in the development of alternative anode materials, extensive efforts have been emphasized on ceria-based cermet [28-40]. By using Cu-ceria composite in place of Ni/YSZ cermet, SOFCs exhibited constant operating voltage and effective catalytic activity in the presence of $\mathrm{H}_{2} \mathrm{~S}$ $[35,36]$. The enhanced sulfur tolerance of the $\mathrm{Cu}$ catalyst was attributed to copper oxide acting as a sulfidation site $[32,34,36,37]$. Gong et al. studied Cu-ceria as the sulfur tolerant anode material for SOFC application and summated that the anode surface and its electronic structure played a key role in achieving sulfur-resistance [30]. Pt and Pd catalysts supported on ceria were also reported to possess effective sulfur tolerant properties [31, 35]. Impregnation of $\mathrm{Ni}$ to Pt supported on ceria exhibited better activity and tolerance in the presence of sulfur [38]. He et al. suggested that an increase of the electron-deficiency of noble metals like $\mathrm{Pt}$ could be essential to increase sulfur tolerance of noble metal catalysts [32]. In effort to understand the surface sulfur interaction with the catalyst at a molecular level, Choi et al. analyzed sulfur tolerance of $\mathrm{Ni}, \mathrm{Cu}$, and $\mathrm{Ni}-\mathrm{Cu}$ alloys for SOFCs using computational ab initio method [39]. 
It was subsequently concluded that $\mathrm{Cu}$ was more sulfurtolerant than $\mathrm{Ni}$, and that alloying $\mathrm{Ni}$ with $\mathrm{Cu}$ improved sulfur tolerance. Recently, computational simulation was performed on four different compositional and nanostructured catalyst materials, that is, pure $\mathrm{Cu}, \mathrm{Cu}-\mathrm{Pt}$ bimetal, $\mathrm{Cu}$-skin-structured $\mathrm{Cu}-\mathrm{Pt}$ bimetal, and Pt-skin structured $\mathrm{Cu}-\mathrm{Pt}$ bimetal. Preliminary results suggested that there was least interaction between the adsorbed sulfur atom and the Pt-skin-structured $\mathrm{Cu}-\mathrm{Pt}$ bimetal catalyst, and hence the most sulfur-resistant among the four candidates [40]. This research is to synthesize $\mathrm{Cu}-\mathrm{Pt}$ bimetal and Pt-skin structured bimetal catalysts supported on nanocrystalline $\mathrm{CeO}_{2}$ which may potentially serve as sulfur-resistant anodes for SOFCs. The low-cost sol-gel method was applied to synthesize nanocrystalline ceria. Impregnation processing was adopted to acquire the catalyst-covered nano-ceria powders. Crystal structure, particle size, bulk composition, and surface composition of the catalyst-coated nano-ceria composites were characterized.

\section{Experimental Aspects}

2.1. Synthesis of Nano-Ceria. Cerium (IV) nitrate hexahydrate (99\% metals basis, Sigma-Aldrich) was added to distilled water until fully dissolved at room temperature. Afterwards, citric acid monohydrate (Sigma-Aldrich) was added in the cerium solution at 1:1 molar ratio to serve as a complexing polyfunctional agent. Two generalized reactions in the sol-gel processing [41] are the following:

$$
\begin{aligned}
\text { Hydrolysis: } & \mathrm{M}^{+}+\left({ }^{-} \mathrm{OOCR}\right)_{n}+x \mathrm{H}_{2} \mathrm{O} \\
& \longrightarrow \mathrm{M}(\mathrm{OOCR})_{n-x}(\mathrm{OH})_{x}+x \mathrm{RCOOH} \\
\text { Condensation: } & 2 \mathrm{M}(\mathrm{OOCR})_{n-x}(\mathrm{OH})_{x} \\
& \longrightarrow\left[(\mathrm{OH})_{x-1}(\mathrm{OOCR})_{n-x} \mathrm{M}\right]_{2} \mathrm{O}+\mathrm{H}_{2} \mathrm{O}
\end{aligned}
$$

where $\mathrm{M}$ and $\mathrm{R}$ represent metal and alkane groups, respectively. After stirred and heated at $80^{\circ} \mathrm{C}$ for 2 hours, the clear solution turned into a viscous gel. The yellow paste was then dried at $250^{\circ} \mathrm{C}$ for 1 hour and calcined at $600^{\circ} \mathrm{C}$ for 5 hours at a ramping rate of $10^{\circ} \mathrm{C}$ per minute in air.

2.2. Synthesis of Catalysts Covered Nano-Ceria. Copper (II) acetate hydrate (Sigma-Aldrich) was added to appropriate amount of distilled water resulting in a molarity of $0.025 \mathrm{M}$ solution. A $0.025 \mathrm{M} \mathrm{Pt-containing} \mathrm{solution} \mathrm{was} \mathrm{prepared} \mathrm{by}$ mixing $1 \mathrm{~mL}$ of concentrated nitric acid, $9 \mathrm{~mL}$ of distilled water, and $0.1 \mathrm{~g}$ of platinum (II) acetylacetonate (SigmaAldrich). The $\mathrm{Cu}$ covered $\mathrm{CeO}_{2}$ ( $\mathrm{Cu}$-Ceria) was synthesized as in the following: $1 \mathrm{~g}$ of nano-ceria powders was placed in the $100 \mathrm{~mL} 0.025 \mathrm{MCu}$ acetate solution, stirred and preserved overnight. It was then filtered, washed, and dried at $250^{\circ} \mathrm{C}$. The $\mathrm{Pt}$ covered $\mathrm{CeO}_{2}$ (Pt-Ceria) followed a similar process. The CuPt bimetallic catalyst supported on $\mathrm{CeO}_{2}$ (bimetal CuPt-ceria) was synthesized via impregnating nano-ceria powder in a mixture of $5 \mathrm{~mL}$ copper-containing solution and $3 \mathrm{~mL}$ of $\mathrm{Pt}$-containing solution in one step.
The Pt-skin-structured CuPt catalyst supported on $\mathrm{CeO}_{2}$ (Pt-skin CuPt-ceria) was synthesized via a sequential twostep impregnation process. The nano-ceria powder was firstly impregnated in the copper acetate solution. After the resultant powder was washed and dried, the $\mathrm{Cu}$-ceria powder was placed in the platinum acetylacetonate solution, filtered, and then dried. All the impregnation is set for 24 hours in sufficient amount of solution to ensure saturated and maximum surface adsorption.

2.3. Characterization of Supported Nano-Ceria Catalysts. The bare nano-ceria and impregnated ceria specimens were subjected to a series of structural, topographical, and compositional analyses with the help of X-ray Diffraction (XRD), Atomic Force Microscopy (AFM), Energy Dispersive X-ray Spectroscopy (EDS), and X-ray Photoelectron Spectroscopy (XPS).

XRD spectra were obtained on the X-ray Diffractometer (Rigaku RU200 DMAX B) in the $2 \theta$ range of $24.0^{\circ}$ to $84.0^{\circ}$ at a step rate of $2^{\circ}$ per minute. AFM topographical imaging was conducted on Agilent 5420 to visualize accurate particle size. The elemental compositions were analyzed by using EDS equipped in the scanning electron microscope (JEOL $7401 \mathrm{~F})$. Two different morphological regions and two area sizes $(10 \mu \mathrm{m}$ by $10 \mu \mathrm{m}$ and $200 \mu \mathrm{m}$ by $180 \mu \mathrm{m}$ ) were selected. Since EDS collects elemental information of a specimen at a depth of $1-5 \mu \mathrm{m}$, the EDS results essentially provide the average bulk composition information [42, 43].

The XPS signals, originating from the outer layers (less than $1-3 \mathrm{~nm}$ ) of a specimen, provide the surface-sensitive information on composition and chemistry [42, 43]. XPS was conducted on Kratos Axis Ultra Instrument and the results were analyzed with the help of CasaXPS software. All spectra were taken using mono-Al K $\alpha$ X-rays $(1486.6 \mathrm{eV})$ and binding energies were reported as measured without correction. XPS survey scans were performed in the binding energy range from $1 \mathrm{eV}$ to $1000 \mathrm{eV}$. The fine scans were focused in the ranges of $870-920 \mathrm{eV}, 930-970 \mathrm{eV}, 525-530 \mathrm{eV}$ and $70-77 \mathrm{eV}$ corresponding to $\mathrm{Cu} 2 \mathrm{p}, \mathrm{Ce} 3 \mathrm{~d}, \mathrm{O} 1 \mathrm{~s}$, and $\mathrm{Pt} 4 \mathrm{f}$ peaks, respectively.

\section{Results and Discussion}

In the XPS survey spectra of the four impregnated specimens, no impurity elements other than $\mathrm{Cu}$ and/or $\mathrm{Pt}, \mathrm{Ce}, \mathrm{O}$ were detected. Fine scans were subsequently carried out in the pertinent binding energy ranges to elucidate the elemental bonding states of the elements of interest. Figure 1 displays the $\mathrm{Cu} 2 \mathrm{p}$ and Pt $4 \mathrm{f}$ XPS fine-scan spectra of the four coated specimens, that is, $\mathrm{Cu}$-ceria, Pt-ceria, bimetal CuPt-ceria, and Pt-skin CuPt-ceria. Both $\mathrm{Pt}$ and $\mathrm{Cu}$ peaks are observable in the bimetal CuPt-ceria achieved by onestep impregnation. However, in the Pt-skin bimetal-ceria achieved via sequential two-step impregnation, the Pt peaks obviously present (see Figure $1(\mathrm{a})$ ) but $\mathrm{Cu}$ peaks are not detected (see Figure 1(b)), distinguished from the bimetalceria specimen. The interesting observations were verified by repeating the measurements. XPS analyses indicated 


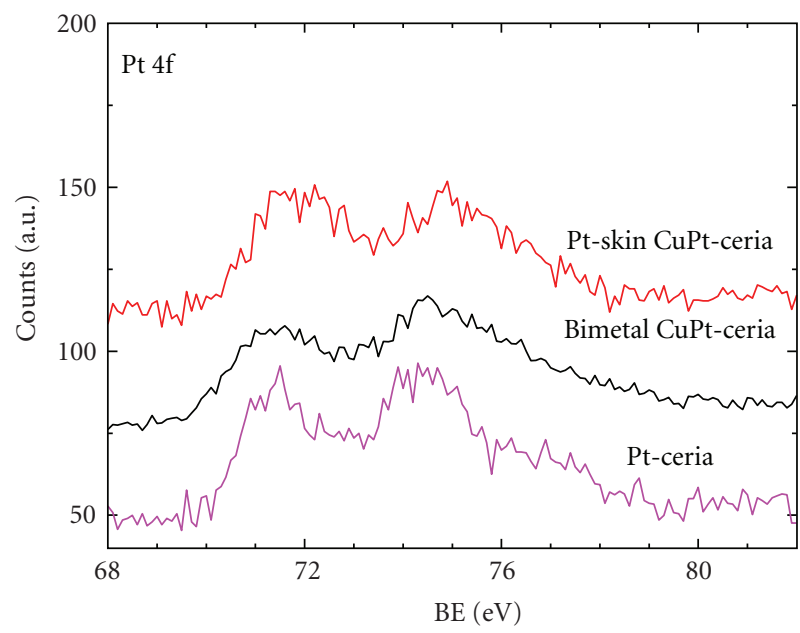

(a)

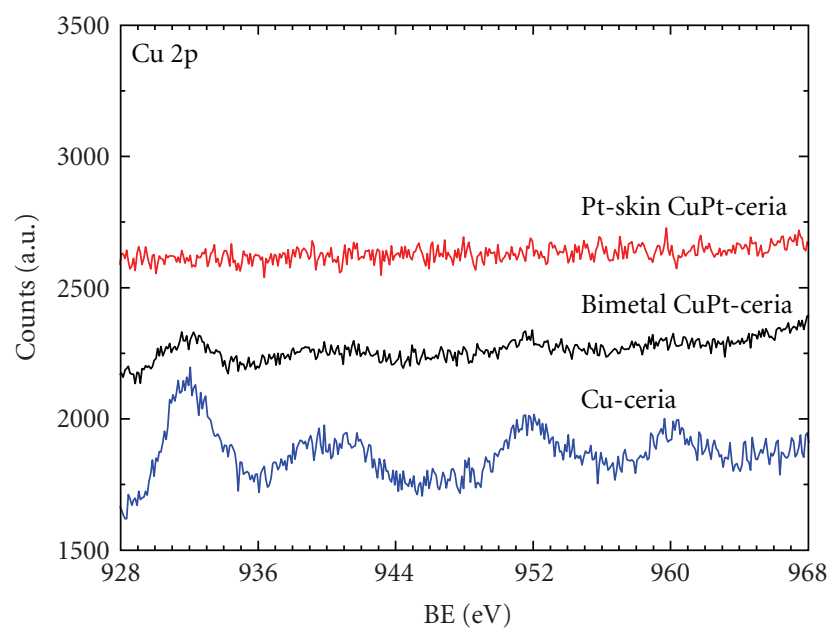

(b)

FIGURE 1: XPS fine-scan spectra of the catalyst specimens coated on nano-ceria in the binding energy ranges (a) Pt $4 \mathrm{f}$ and (b) Cu 2p.

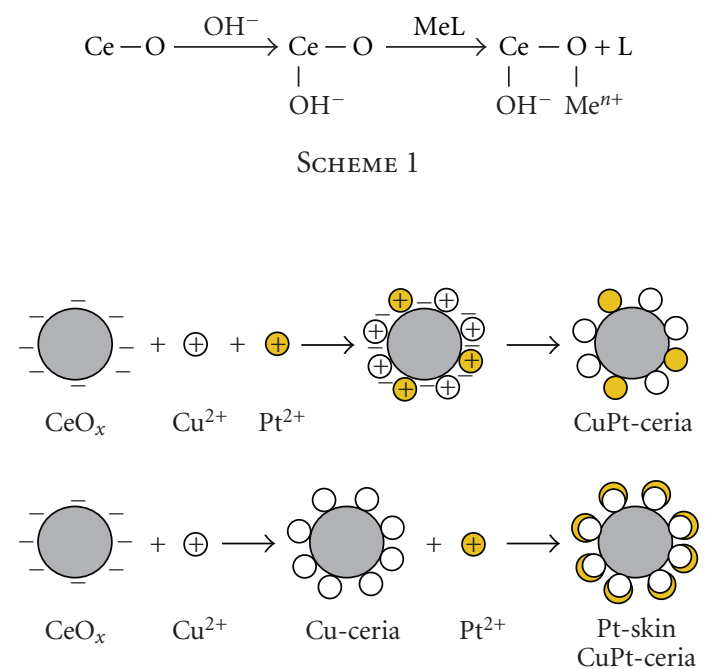

FIGURE 2: Schematics of adsorption and formation of CuPt-ceria and Pt-skin CuPt-ceria composites.

that the outer layers (less than a few nm thick) of the specimen prepared by impregnation in two-step sequence were predominantly $\mathrm{Pt}$, resulting in the Pt-skin structure.

It has been discovered that depending on the structure and adsorption mechanism, only a small portion of all sites on oxides are active for cation sorption. On silica and zeolites, surface hydroxyl groups were involved in the adsorption of cations on oxide [44], but on titania the coordinatively unsaturated $\mathrm{Ti}^{4+}-\mathrm{O}^{2-}$ couples were the active adsorption sites [45]. Vassileva et al., with the aid of IR spectroscopy, summated that hydroxyl groups participated in the the heavy metal ion adsorption on ceria [46]. The adsorption scheme can be expressed as shown in Scheme 1. where $\mathrm{Me}^{n+}$ is the heavy metal cation and $\mathrm{L}$ is the ligand. The scheme explained the blocking of the Ce sites after cation adsorption. Accordingly, the cation adsorption, after

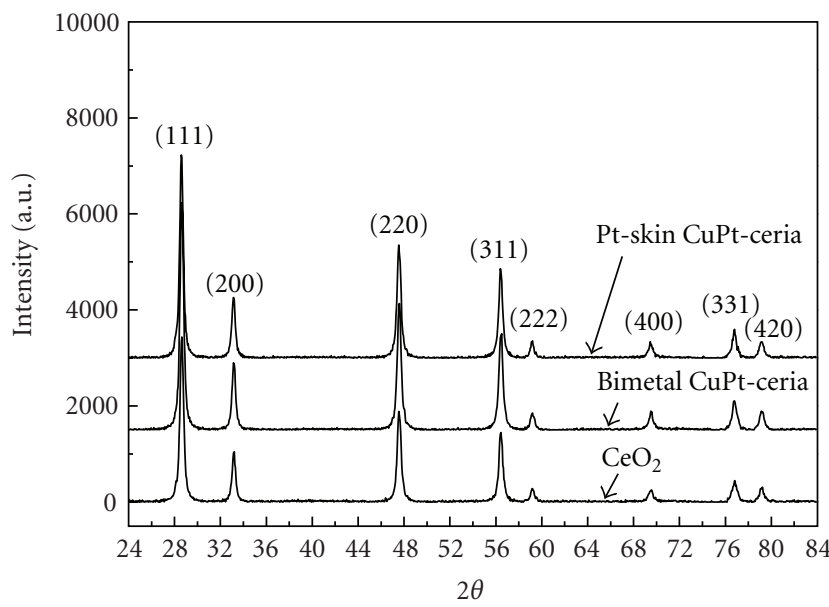

Figure 3: Diffraction spectra of the bare ceria, CuPt-ceria, and Ptskin CuPt-ceria.

impregnation to formation of the bimetal CuPt-ceria, and Pt-skin CuPt-ceria were schematically illustrated in Figure 2.

EDS analysis, capable to detect the elements in the depth up to a few micrometers, was performed on the Pt-skinstructured materials and confirmed the coexistence of $\mathrm{Cu}$ and $\mathrm{Pt}$ in the specimen. Aided by the quantitative analysis software included with ZAF correction, the average bulk composition of the $\mathrm{Cu}$ and $\mathrm{Pt}$ elements in the composite was determined $3.7 \mathrm{wt} \%$ and $1.0 \mathrm{wt} \%$, respectively. It needs to note that the Pr and Sm elements were also detected in the EDS spectrum, which were originated from the cerium acetate precursors. Due to the similar size and charge of Pr, $\mathrm{Sm}$ to Ce, the two elements are very soluble and usually exist in the ceria fluorite structure [47]. In contrast, $\mathrm{Cu}$ and $\mathrm{Pt}$ are barely soluable in ceria and hence may be absorbed on the surface in ceria, which were manifested by XPS results.

XRD diffraction spectra of bare ceria, bimetal CuPtceria, and Pt-skin CuPt-ceria are presented in Figure 3. 


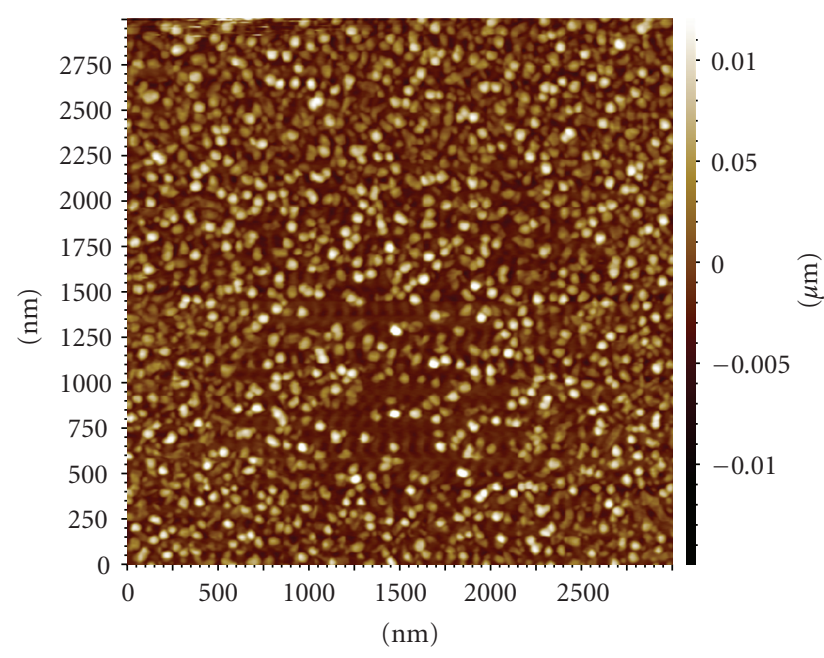

FIGURe 4: AFM image of the sol-gel-synthesized Pt-skin CuPt-ceria.

Apparently, all the diffraction peak heights and positions properly matched the corresponding values associated with the fluorite-structured cubic $\mathrm{CeO}_{2}$ [48]. No visible peaks related to metallic $\mathrm{Cu}, \mathrm{Pt}$, or their oxide phases emerged in the impregnated samples. Further careful examination indicated insignificant position shifts occurred in comparison with bare nano-ceria. These observations may imply that the absorbed $\mathrm{Cu}$ and/or $\mathrm{Pt}$ is neither present in the crystallographic structure nor incorporated into the ceria structure, suggesting possible amorphous phase. Alternatively, the observation may be the consequence of the low loading level of catalytic elements (based on the EDS analysis), undetectable by XRD $[42,43]$. The actual phase of the metallic catalyst will be subjected to further investigations by using transmission electron microscopy and electron diffraction in the future.

The particle size of the Pt-skin CuPt-ceria, visualized from the AFM topographical image, is $63 \mathrm{~nm}$ in average (see Figure 4). These results are corroborated well with the broadening of the XRD peaks. This value is slightly larger than that of uncoated ceria which has an average particle size of $60 \mathrm{~nm}$. Accordingly, the average catalyst particles are estimated about $3 \mathrm{~nm}$, vital to the catalytic efficiency. Further, cerium and oxygen composition in bare nano-ceria were quantified based on the EDS data, with oxygen to cerium ratio in the range from 1.7 to 1.9. The nonstoichiometry of the nano-ceria $\left(\mathrm{CeO}_{x}\right)$ indicated more oxygen vacancy and higher electronic conductivity than $\mathrm{CeO}_{2}$, which will be beneficial to the reaction between hydrogen and oxygen ion on the anode side of SOFCs [49-51]. Moreover, a portion of the $\mathrm{Cu}$-ceria specimen was subjected to reduction in a hydrogen atmosphere at $600^{\circ} \mathrm{C}$ to simulate the practical SOFC operating conditions. Figure 5 exhibits $\mathrm{Cu} 2 \mathrm{p}$ XPS spectra of the $\mathrm{Cu}$-ceria sample before and after reduction. The coexistence of $\mathrm{Cu} 2 \mathrm{p} 3 / 2$ and the typical $\mathrm{Cu} 2 \mathrm{p} 1 / 2$ shake-up satellites in the $\mathrm{Cu}$-coated ceria at $939.8 \mathrm{eV}$ and $960.0 \mathrm{eV}$, as can be seen in Figure 5, indicated the presence

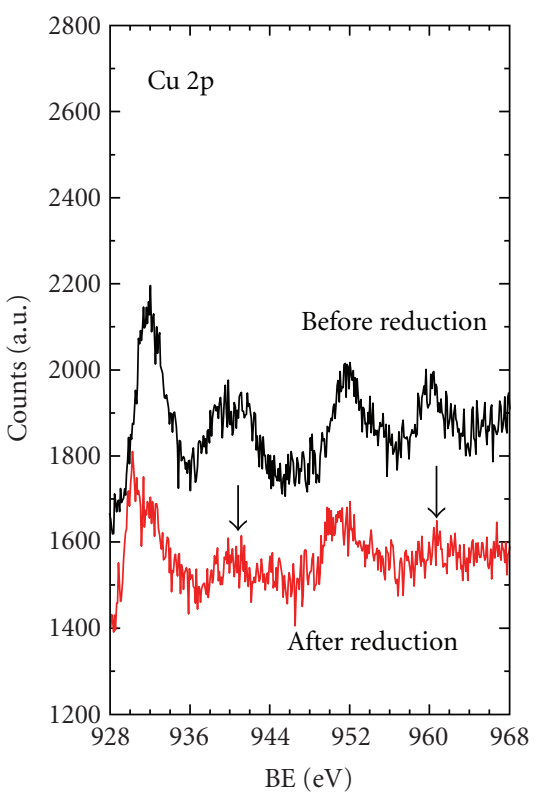

FIgure 5: Comparison of XPS fine-scan spectra of the Cu-coated ceria specimen before (above) and after reduction (bottom) at $600^{\circ} \mathrm{C}$ in the binding energy ranges of $\mathrm{Cu} 2 \mathrm{p}$.

of $\mathrm{Cu}^{2+}$ ion in the oxide state. After the reduction process, the $\mathrm{Cu}$ satellite peaks decreased significantly, marked by the arrows in the figure. The results suggested copper in the as-prepared $\mathrm{Cu}$-coated ceria existed in the oxidized state, but could be successfully reduced at the SOFC operational temperatures.

\section{Conclusion}

CuPt bimetal and Pt-skin CuPt bimetal catalysts coated on nanocrystalline $\mathrm{CeO}_{2}$ were successfully achieved via the costeffective sol-gel approach followed by one-step or two-step sequential impregnation. The nano-ceria supporter had a fluorite structure.

The $\mathrm{Cu}$ and/or Pt on the ceria surface, not detected by XRD, may exist in an amorphous phase although not conclusive yet. The average particle size of the catalyst coated ceria was $63 \mathrm{~nm}$ with the catalyst layer around $3 \mathrm{~nm}$. $\mathrm{Cu}$ components, present in an oxidic state, can be readily reduced into a metallic state under fuel cell operating conditions. The CuPt bimetal and Pt-skin CuPt-ceria may be promising anode alternatives for SOFCs powered by sulfurcontaining fuels. Performances of SOFCs made up of the novel formula anode under sulfur-constaning fuels are still under investigation.

\section{Acknowledgments}

The authors would like to acknowledge the Ohio Space Grant Consortium and Wright State University for the financial support of this research. 


\section{References}

[1] S. C. Singhal, "Advances in solid oxide fuel cell technology," Solid State Ionics, vol. 135, no. 1-4, pp. 305-313, 2000.

[2] S. M. Haile, "Fuel cell materials and components," Acta Materialia, vol. 51, no. 19, pp. 5981-6000, 2003.

[3] B. C. H. Steele and A. Heinzel, "Materials for fuel-cell technologies," Nature, vol. 414, no. 6861, pp. 345-352, 2001.

[4] N. P. Brandon, S. Skinner, and B. C. H. Steele, "Recent advances in materials for fuel cells," Annual Review of Materials Research, vol. 33, pp. 183-213, 2003.

[5] B. C. H. Steele, "Fuel-cell technology: running on natural gas," Nature, vol. 400, no. 6745, pp. 619-621, 1999.

[6] A. L. Dicks, "Hydrogen generation from natural gas for the fuel cell systems of tomorrow," Journal of Power Sources, vol. 61, no. 1-2, pp. 113-124, 1996.

[7] E. Shoko, B. McLellan, A. L. Dicks, and J. C. D. da Costa, "Hydrogen from coal: production and utilisation technologies," International Journal of Coal Geology, vol. 65, no. 3-4, pp. 213-222, 2006.

[8] M. Ormerod and J. Staniforth, "Running fuel cells on biogasa renewable fuel," Green Chemistry, vol. 3, no. 5, pp. G61-G63, 2001.

[9] I. C. Lee and H. C. Ubanyionwu, "Determination of sulfur contaminants in military jet fuels," Fuel, vol. 87, no. 3, pp. 312 318, 2008.

[10] M. Komiyama, T. Misonou, S. Takeuchi, K. Umetsu, and J. Takahashi, "Biogas as a reproducible energy source: its steam reforming for electricity generation and for farm machine fuel," International Congress Series, vol. 1293, pp. 234-237, 2006.

[11] B. Aldrich, S. Minott, and N. Scott, "Feasibility of fuel cells for biogas energy conversion on diary farms," Manure Management Program Report, 2005.

[12] K. Cowey, K. J. Green, G. O. Mepsted, and R. Reeve, "Portable and military fuel cells," Current Opinion in Solid State and Materials Science, vol. 8, no. 5, pp. 367-371, 2004.

[13] S. Wang, M. Liu, and J. Winnick, "Stabilities and electrical conductivities of electrode materials for use in HS-containing gases," Journal of Solid State Electrochemistry, vol. 5, no. 3, pp. 188-195, 2001.

[14] Y. Matsuzaki and I. Yasuda, "Poisoning effect of sulfurcontaining impurity gas on a SOFC anode: part I. Dependence on temperature, time, and impurity concentration," Solid State Ionics, vol. 132, no. 3, pp. 261-269, 2000.

[15] K. Sasaki, K. Susuki, A. Iyoshi et al., "HS poisoning of solid oxide fuel cells," Journal of the Electrochemical Society, vol. 153, no. 11, pp. A2023-A2029, 2006.

[16] J. P. Trembly, A. I. Marquez, T. R. Ohrn, and D. J. Bayless, "Effects of coal syngas and HS on the performance of solid oxide fuel cells: single-cell tests," Journal of Power Sources, vol. 158, no. 1, pp. 263-273, 2006.

[17] L. Aguilar, S. Zha, Z. Cheng, J. Winnick, and M. Liu, "A solid oxide fuel cell operating on hydrogen sulfide (HS) and sulfurcontaining fuels," Journal of Power Sources, vol. 135, no. 1-2, pp. 17-24, 2004.

[18] F. P. Nagel, T. J. Schildhauer, J. Sfeir, A. Schuler, and S. M. A. Biollaz, "The impact of sulfur on the performance of a solid oxide fuel cell (SOFC) system operated with hydrocarboneous fuel gas," Journal of Power Sources, vol. 189, no. 2, pp. 11271131, 2009.
[19] Z. F. Zhou, C. Gallo, M. B. Pague, H. Schobert, and S. N. Lvov, "Direct oxidation of jet fuels and Pennsylvania crude oil in a solid oxide fuel cell," Journal of Power Sources, vol. 133, no. 2, pp. 181-187, 2004.

[20] T. R. Smith, A. Wood, and V. I. Birss, "Effect of hydrogen sulfide on the direct internal reforming of methane in solid oxide fuel cells," Applied Catalysis A: General, vol. 354, no. 1-2, pp. 1-7, 2009.

[21] M. Liu, P. He, J. L. Luo, A. R. Sanger, and K. T. Chuang, "Performance of a solid oxide fuel cell utilizing hydrogen sulfide as fuel," Journal of Power Sources, vol. 94, no. 1, pp. 20$25,2001$.

[22] J. Dong, Z. Cheng, S. Zha, and M. Liu, "Identification of nickel sulfides on Ni-YSZ cermet exposed to $\mathrm{H}_{2}$ fuel containing $\mathrm{H}_{2} \mathrm{~S}$ using Raman spectroscopy," Journal of Power Sources, vol. 156, no. 2, pp. 461-465, 2006.

[23] A. Atkinson, S. Barnett, R. J. Gorte et al., "Advanced anodes for high-temperature fuel cells," Nature Materials, vol. 3, no. 1, pp. 17-27, 2004.

[24] D. Weaver and J. Winnick, "Utilization of hydrogen sulfide in an intermediate-temperature ceria-based solid oxide fuel cell," Journal of the Electrochemical Society, vol. 136, pp. 1679-1686, 1998.

[25] Y. M. Choi, C. Compson, M. C. Lin, and M. Liu, "A mechanistic study of HS decomposition on $\mathrm{Ni}$ - and $\mathrm{Cu}$-based anode surfaces in a solid oxide fuel cell," Chemical Physics Letters, vol. 421, no. 1-3, pp. 179-183, 2006.

[26] A. Trovarelli, C. De Leitenburg, M. Boaro, and G. Dolcetti, "The utilization of ceria in industrial catalysis," Catalysis Today, vol. 50, no. 2, pp. 353-367, 1999.

[27] Z. Zhan and S. A. Barnett, "An octane-fueled solid oxide fuel cell," Science, vol. 308, no. 5723, pp. 844-847, 2005.

[28] H. Kurokawa, L. Yang, C. P. Jacobson, L. C. De Jonghe, and S. J. Visco, "Y-doped $\mathrm{SrTiO}_{3}$ based sulfur tolerant anode for solid oxide fuel cells," Journal of Power Sources, vol. 164, no. 2, pp. 510-518, 2007.

[29] H. Kim, J. M. Vohs, and R. J. Gorte, "Direct oxidation of sulfur-containing fuels in a solid oxide fuel cell," Chemical Communications, vol. 22, pp. 2334-2335, 2001.

[30] M. Gong, X. Liu, J. Trembly, and C. Johnson, "Sulfur-tolerant anode materials for solid oxide fuel cell application," Journal of Power Sources, vol. 168, no. 2, pp. 289-298, 2007.

[31] Y. Yoshimura, M. Toba, T. Matsui et al., "Active phases and sulfur tolerance of bimetallic Pd-Pt catalysts used for hydrotreatment," Applied Catalysis A: General, vol. 322, pp. 152-171, 2007.

[32] H. He, R. J. Gorte, and J. M. Vohs, "Highly sulfur tolerant $\mathrm{Cu}$-ceria anodes for SOFCs," Electrochemical and Solid-State Letters, vol. 8, no. 6, pp. A279-A280, 2005.

[33] H. Devianto, S. P. Yoon, S. W. Nam, J. Han, and T. H. Lim, "The effect of a ceria coating on the HS tolerance of a molten carbonate fuel cell," Journal of Power Sources, vol. 159, no. 2, pp. 1147-1152, 2006.

[34] R. J. Gorte, H. Kim, and J. M. Vohs, "Novel SOFC anodes for the direct electrochemical oxidation of hydrocarbon," Journal of Power Sources, vol. 106, no. 1-2, pp. 10-15, 2002.

[35] A. M. Azad, M. J. Duran, A. K. McCoy, and M. A. Abraham, "Development of ceria-supported sulfur tolerant nanocatalysts: Pd-based formulations," Applied Catalysis A: General, vol. 332, no. 2, pp. 225-236, 2007.

[36] V. P. Pakharukova, E. M. Moroz, V. V. Kriventsov, D. A. Zyuzin, G. R. Kosmambetova, and P. E. Strizhak, "Copper-cerium oxide catalysts supported on monoclinic zirconia: structural features and catalytic behavior in preferential oxidation of 
carbon monoxide in hydrogen excess," Applied Catalysis A: General, vol. 365, no. 2, pp. 159-164, 2009.

[37] H. P. He, A. Wood, D. Steedman, and M. Tilleman, "Sulphur tolerant shift reaction catalysts for nickel-based SOFC anode," Solid State Ionics, vol. 179, no. 27-32, pp. 1478-1482, 2008.

[38] H. Kurokawa, T. Z. Sholklapper, C. P. Jacobson, L. C. De Jonghe, and S. J. Visco, "Ceria nanocoating for sulfur tolerant Ni-based anodes of solid oxide fuel cells," Electrochemical and Solid-State Letters, vol. 10, no. 9, pp. 135-138, 2007.

[39] Y. M. Choi, C. Compson, M. C. Lin, and M. Liu, "Ab initio analysis of sulfur tolerance of $\mathrm{Ni}, \mathrm{Cu}$, and $\mathrm{Ni}-\mathrm{Cu}$ alloys for solid oxide fuel cells," Journal of Alloys and Compounds, vol. 427, no. 1-2, pp. 25-29, 2007.

[40] J. F. Bozeman III, Sulfur-Tolerant Catalyst for the Solid Oxide Fuel Cells, OhioLINK Electronic Thesis and Dissertation Center, 2010.

[41] C. J. Brinker and G. W. Sherer, Sol-Gel Science: The Physics and Chemistry of Sol-Gel Processing, Academic Press, New York, NY, USA, 1st edition, 1990.

[42] D. Brandon and W. D. Kaplan, Microstrucutral Characterization of Materials, John Wiley \& Sons, New York, NY, USA, 2nd edition, 2007.

[43] J. B. Wachtman, Characterizations of Materials, ButternworthHeinemann, 1993.

[44] J. A. Schwarz, C. Contescu, and A. Contescu, "Methods for preparation of catalytic materials," Chemical Reviews, vol. 95, no. 3, pp. 477-510, 1995.

[45] K. Hadjiivanov, D. Klissurski, M. Kantcheva, and A. Davydov, "State and localization of cobalt, nickel and copper ions adsorbed on titania (anatase)," Journal of the Chemical Society, Faraday Transactions, vol. 87, no. 6, pp. 907-911, 1991.

[46] E. Vassileva, B. Varimezova, and K. Hadjiivanov, "Column solid-phase extraction of heavy metal ions on a high surface area $\mathrm{CeO}_{2}$ as a preconcentration method for trace determination," Analytica Chimica Acta, vol. 336, no. 1-3, pp. 141-150, 1996.

[47] J. Ranløv, F. W. Poulsen, and M. Mogensen, "Comment on 'The characterization of doped $\mathrm{CeO}$ electrodes in solid oxide fuel cells", Solid State Ionics, vol. 61, no. 4, pp. 277-279, 1993.

[48] M. Mogensen, N. M. Sammes, and G. A. Tompsett, "Physical, chemical and electrochemical properties of pure and doped ceria," Solid State Ionics, vol. 129, no. 1, pp. 63-94, 2000.

[49] T. Suzuki, I. Kosacki, and H. U. Anderson, "Defect and mixed conductivity in nanocrystalline doped cerium oxide," Journal of the American Ceramic Society, vol. 85, no. 6, pp. 1492-1498, 2002.

[50] H. Huang, T. Holme, and F. B. Prinz, "Increased cathodic kinetics on platinum in IT-SOFCs by inserting highly ionicconducting nanocrystalline materials," Journal of Fuel Cell Science and Technology, vol. 7, no. 4, Article ID 041012, pp. $1-5,2010$.

[51] E. Ruiz-Trejo, J. D. Sirman, Y. U. M. Baikov, and J. A. Kilner, "Oxygen ion diffusivity, surface exchange and ionic conductivity in single crystal Gadolinia doped Ceria," Solid State Ionics, vol. 113-115, pp. 565-569, 1998. 

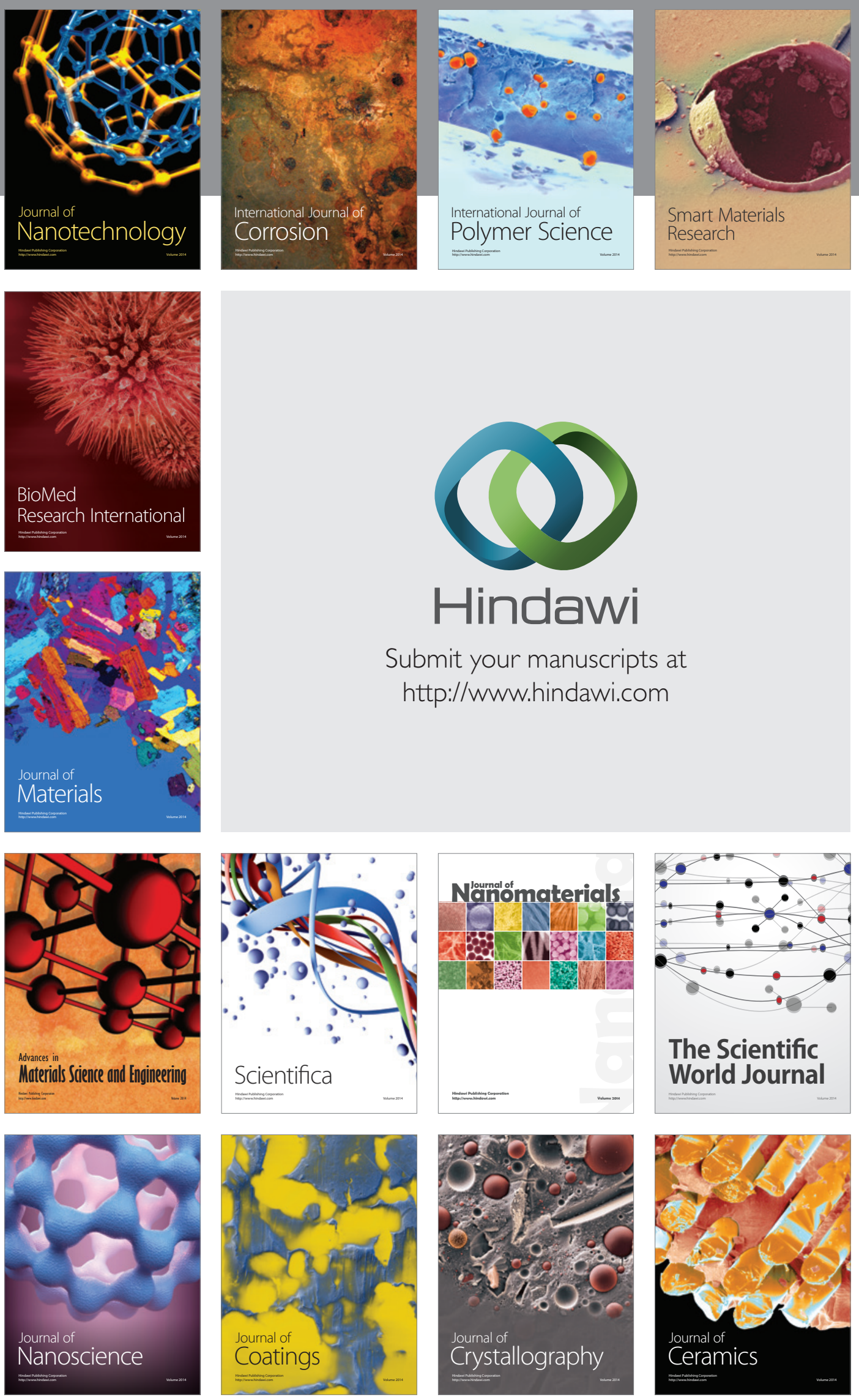

The Scientific World Journal

Submit your manuscripts at

http://www.hindawi.com

\section{World Journal}

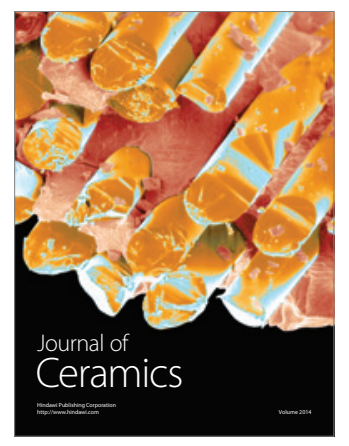

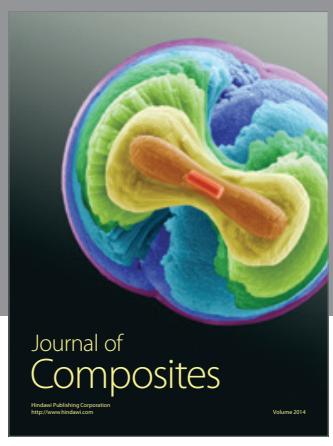
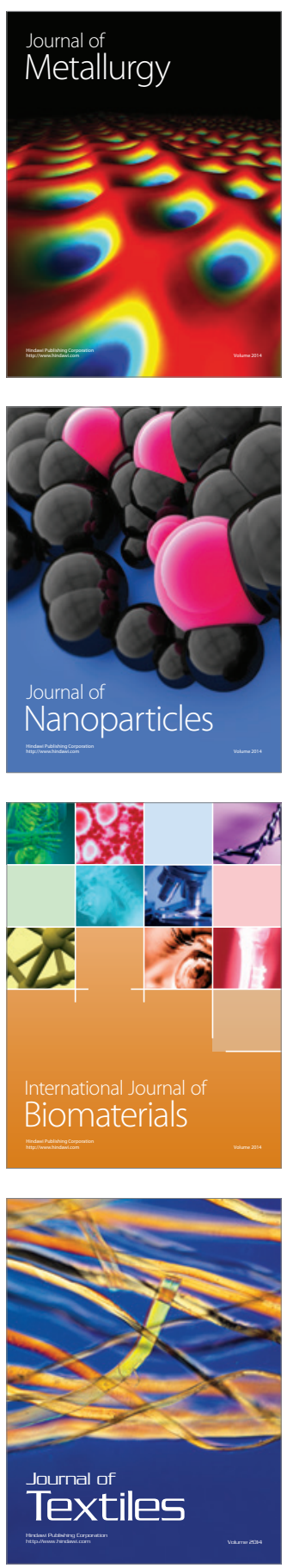